Article

\title{
The Influence of the mineral-Microbial Preparation on Ammonia Concentration and Productivity in Laying Hens Houses
}

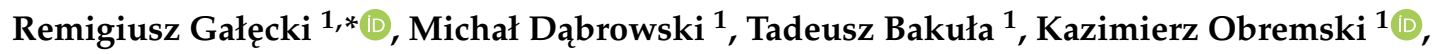 \\ Adriana Nowak ${ }^{2}$ and Beata Gutarowska ${ }^{2}$ \\ 1 Department of Veterinary Prevention and Feed Hygiene, Faculty of Veterinary Medicine, University of \\ Warmia and Mazury in Olsztyn, 10-718 Olsztyn, Poland; michal.dabrowski@uwm.edu.pl (M.D.); \\ bakta@uwm.edu.pl (T.B.); kazimierz.obremski@uwm.edu.pl (K.O.) \\ 2 Department of Environmental Biotechnology, Faculty of Biotechnology and Food Science, Lodz University \\ of Technology, 90-924 Łódź, Poland; adriana.nowak@p.lodz.pl (A.N.); beata.gutarowska@p.lodz.pl (B.G.) \\ * Correspondence: remigiusz.galecki@uwm.edu.pl
}

Received: 13 October 2019; Accepted: 25 November 2019; Published: 28 November 2019

check for updates

\begin{abstract}
The aim of this study was to evaluate the influence of the biopreparation Deodoric ${ }^{\circledR}$ on ammonia $\left(\mathrm{NH}_{3}\right)$ concentration, performance, and hygiene standards in laying hen (ROSS-308) production. Statistically significant differences in $\mathrm{NH}_{3}$ concentration and the body weight of laying hens were observed between the control group $(C)$ and the experimental group (E) where Deodoric ${ }^{\circledR}$ was applied at the set dose. In the control group, an increase in $\mathrm{NH}_{3}$ concentration could have contributed to the decrease in the body weight of laying hens, egg production, and $\%$ hen day egg production, whereas no such correlations were observed in the experimental group. A moderate linear correlation between $\mathrm{NH}_{3}$ concentration vs. humidity $(r=0.68)$, air flow $(r=0.48)$ and weakly linear correlation between $\mathrm{NH}_{3}$ concentration and age of birds $(r=0.27)$ was noted in group $\mathrm{C}$. In group $\mathrm{E}, \mathrm{NH}_{3}$ concentration vs. temperature $(r=0.27)$ and humidity $(r=0.14)$ were weakly correlated. Statistical analysis of changes in the microbial counts isolated from manure revealed a significant decrease of mesophilic microorganisms on day 28 decrease of Campylobacter spp. days 14 and 84 in group E. However, for the entire experimental model no statistically significant changes in the number of Campylobacter spp. and mesophilic bacteria were found. The tested preparation did not cause changes in the microbial composition of tissue swabs. Deodoric ${ }^{\circledR}$ contributes to animal welfare by reducing the ammonia concentrations in poultry houses. It is also recommended for use in poultry farms to improve animal health and performance and to generate benefits for producers.
\end{abstract}

Keywords: ammonia; deodorizing additive; prevention; farm hygiene; poultry

\section{Introduction}

Ammonia $\left(\mathrm{NH}_{3}\right)$ is one of the most prevalent odorous gases that occur in relatively high concentrations in the agriculture sector. To date, this problem is caused mainly in livestock production [1,2]. In 1990, global $\mathrm{NH}_{3}$ emissions were estimated at $54 \mathrm{Tg} \mathrm{N} \mathrm{yr}^{-1}$ [3]. In 2018, the largest emitters of ammonia from the agricultural sector were India and China followed by North America and Europe [4]. Animal production is responsible for approximately $75 \%$ of global $\mathrm{NH}_{3}$ emissions which are encountered in all stages of breeding [5]. Pig, dairy, cattle, and poultry farms are regarded as the main sources of $\mathrm{NH}_{3}$ in the agricultural sector [6]. Webb et al. [5] and Van der Hoek [7] demonstrated that animal excreta is responsible for approximately $75-80 \%$ of $\mathrm{NH}_{3}$ emissions in agriculture (average based on European systems). In Germany, poultry farming is responsible for 
$6 \%$ of $\mathrm{NH}_{3}$ emissions in agriculture [8]. Despite the above, this problem has not yet been adequately addressed by poultry producers. One laying hen produces $0.37 \mathrm{~kg} \mathrm{NH}_{3}$ animal ${ }^{-1} \mathrm{yr}^{-1}$, one broiler chicken $0.28 \mathrm{~kg} \mathrm{NH}_{3}$ animal ${ }^{-1} \mathrm{yr}^{-1}$, and one turkey $0.92 \mathrm{~kg} \mathrm{NH}_{3}$ animal ${ }^{-1} \mathrm{yr}^{-1}$ [7]. Ammonia can exert a negative influence on farm employees and livestock. In European countries, the $\mathrm{NH}_{3}$ threshold for all animals kept indoors is $20 \mathrm{ppm}$ [9]. The threshold exposure limit to $\mathrm{NH}_{3}$ concentration of 35 ppm for humans has been set at $15 \mathrm{~min}$ by the American Conference of Governmental Industrial Hygienists [10]. Exposure to $\mathrm{NH}_{3}$ concentration of $300 \mathrm{ppm}$ could pose a threat to human health and life [11]. Research has demonstrated that $\mathrm{NH}_{3}$ impairs poultry growth and increases susceptibility to disease $[12,13]$. Ammonia and other odorous gases pose a threat to the environment and living organisms. Future research should focus on reducing odorous gas emissions [14-17].

Housing conditions, including $\mathrm{NH}_{3}$ concentration, have a greater influence on animal welfare than stocking density [18], which is why $\mathrm{NH}_{3}$ concentration in farms should be strictly monitored. There are no commercial microbial preparations for decreasing $\mathrm{NH}_{3}$ concentration in poultry farms. According to Whyte [19], dust and gas concentrations in animal farms can be only partially controlled. Various methods for decreasing $\mathrm{NH}_{3}$ concentration in animal farms have been proposed in the literature, but very few of them rely on a similar mechanism of action as the described deodorizing preparation. At present, $\mathrm{NH}_{3}$ concentration, for example, in pig farms is controlled with the use of biofilters [20] and feed additives which are expensive and not always reliable to poultry farms. Various chemical gases for decreasing $\mathrm{NH}_{3}$ levels in livestock production have been proposed, including alum $\left(\mathrm{Al}_{2}\left(\mathrm{SO}_{4}\right)_{3} \cdot 18 \mathrm{H}_{2} \mathrm{O}\right)$, ferrous sulfate heptahydrate $\left(\mathrm{FeSO}_{4} \cdot 7 \mathrm{H}_{2} \mathrm{O}\right)$, and phosphoric acid $\left(\mathrm{H}_{3} \mathrm{PO}_{4}\right)[21,22]$. In a study by Santoso et al. [23], chicken diets supplemented with dried Bacillus subtilis cultures significantly lowered $\mathrm{NH}_{3}$ levels in poultry houses. Matusiak et al. [24] suggested that a 5\% extract of Yucca schidigera have antimicrobial properties; it sterilized chicken excreta, decreased microbial counts, and enhanced the deodorizing properties of the tested biopreparation.

An innovative microbiological-mineral deodorizing preparation (Deodoric ${ }^{\circledR}$ ) was developed to reduce the ammonia and volatile odorous compounds in poultry houses. This product is composed of six highly active bacterial strains (Pseudomonas fluorescens LOCK0961, Enterococcus faecium LOCK0965, Bacillus subtilis LOCK0962, Bacillus megaterium LOCK0963, Leuconostoc mesenteroides LOCK0964, and Lactobacillus plantarum LOCK 0981, in the form of spray-dried microcapsules, the microcapsules contribute $20 \%$ of the weight of the product) which reduce the content of volatile odorous compounds from poultry manure and minimize antagonistic interactions between the strains. The product also contains a mixture of perlite and bentonite ( $20: 80$ by weight) as the mineral sorbent. Deodoric ${ }^{\circledR}$ was prepared according to the procedure described by Borowski et al. [25].

In previous research, attempts have been made to minimize odor emissions in poultry farms with the use of Deodoric ${ }^{\circledR}$. The deodorizing biopreparation was found to inhibit the growth of potentially pathogenic microorganisms in poultry manure [26]. It effectively decreased ammonia, dimethylamine, trimethylamine, isobutyric acid, and hydrogen sulphide in laboratory conditions, especially ammonia whose concentration in exhaust air was reduced by more than $90 \%$ after 2 days [26]. Described biopreparation also induced a $60-78 \%$ decrease in the concentrations of many other odorants [27]. Previous studies on the development of the Deodoric ${ }^{\circledR}$ biopreparation formula were performed to evaluate the mechanisms of action for 2 parts of preparation: Microbial and mineral $[27,28]$. These published studies on the impact of sorbent without microorganisms proved that sorbent mainly affected the drying of the manure, but also the decreasing of about $30-70 \%$ of four odorant levels, depending on the compound. The microorganisms showed an antagonistic effect against the microorganisms decomposing the manure, as well as influencing the reduction of the odorants concentration in the range of $20-40 \%$, depending on the compound. It was also proved that microorganisms included in the biopreparation compete with odorogenic microorganisms for carbon and nitrogen compounds (mainly aminoacids) $[27,28]$. Thus, the mechanism of action of Deodoric ${ }^{\circledR}$ consists of reducing the concentration of odorants, drying litter, inhibiting the development of potentially pathogenic microorganisms, and improving zootechnical conditions in livestock rooms. 
In previous studies samples of poultry manure $(2-5 \mathrm{~kg})$ were examined under laboratory conditions (this stage of research involved assessments of odorant reduction, methods of application and doses, the sorbent's influence, microbiological analyses, and determination of the biopreparation's composition). Groups of animals (5 individuals per group) were studied under modelled conditions in 3 replications (this stage of research involved assessments of odorant reduction, methods of application and doses, the sorbent's influence, microbiological analyses, and an evaluation of microclimate parameters). The presented experiment is a continuation of the research conducted under laboratory and modelled conditions.

The aim of this study was to evaluate the influence of the Deodoric ${ }^{\circledR}$ deodorizing preparation on $\mathrm{NH}_{3}$ concentration, influence on correlations between $\mathrm{NH}_{3}$ levels and selected microclimatic parameters, and production performance of laying hens in semitechnical scale.

\section{Experiments}

\subsection{Ethical Guidelines}

Procedures were performed in accordance with the guidelines for Care and Use of Laboratory Animals of the Faculty of Veterinary Medicine at University Warmia and Mazury in Olsztyn and the National Research Council [29]. The number of birds in the experiment and the number of repetitions of the experimental design was determined based on the guidelines/provisions of the Local Ethics Committee. In order to preserve the 3R (Replace, Reduce and Refine) principle and obtain statistically significant results of the experiment, the duration of the experiment was extended.

\subsection{Laying Hens and Production Premises}

On 25 October 2016, 17-week-old ROSS-308 laying hens were transported from an industrial farm to the laboratory of the Department of Avian Diseases, Faculty of Veterinary Medicine of the University of Warmia and Mazury in Olsztyn. The experiment lasted 145 days, and hens were euthanized on 27 March 2017 in the experimental abattoir of the Department of Commodity Science and Animal Improvement, Faculty of Animal Bioengineering of the University of Warmia and Mazury in Olsztyn.

The birds were divided into two groups: A control group of 60 hens and 6 roosters without the Deodoric ${ }^{\circledR}$ biopreparation $(C)$ and an experimental group of 60 hens and 6 roosters where Deodoric ${ }^{\circledR}$ was applied (E). Stocking density was 5.5 birds per $1 \mathrm{~m}^{2}$ and it was identical to that in the commercial farms and consistent with the relevant requirements. The experimental premises $\left(12 \mathrm{~m}^{2}\right)$ were equipped with standard animal rearing systems with automatic temperature $\left(20^{\circ} \mathrm{C}\right)$ and ventilation control (humidity $70 \%$ ) that were similar to those used in commercial poultry farms. The birds were fed restricted rations as recommended in "ROSS Parent Stock Management Manual and ROSS-308 Laying Hen Nutrition Specifications" twice daily with ad libitum access to water. The birds were kept in barn conditions similar to those found on commercial farms. The birds were kept on litter from shredded straw (depth of $20 \mathrm{~cm}$ ). The first layer of straw was added on a clean floor. Once a week, every poultry house was supplied with the same amount of fresh wheat straw which was added to the existing straw.

\subsection{Deodoric ${ }^{\circledR}$ Biopreparation}

Two kilograms of Deodoric ${ }^{\circledR}$ were applied based on the following calculations: 66 birds (60 hens and 6 roosters) $/ 12 \mathrm{~m}^{2}=5.5$ birds per $\mathrm{m}^{2}$, rounded off to 6 birds per $\mathrm{m}^{2}$, approximately $1 \mathrm{~kg}$ of excreta (adult birds) per $\mathrm{m}^{2}$, i.e., $7 \mathrm{~kg}$ of excreta per week, $5 \mathrm{~g}$ of dried bacterial strains per $500 \mathrm{~g}$ of excreta (effective dose determined under laboratory conditions by Gutarowska et al. [28], i.e., $70 \mathrm{~g}$ of dried bacterial strains) per week $/ \mathrm{m}^{2}, 100 \mathrm{~g}$ of mineral sorbent $+70 \mathrm{~g}$ of dried bacterial stains $=170 \mathrm{~g}$ of Deodoric ${ }^{\circledR} /$ week $/ \mathrm{m}^{2}$, and $170 \mathrm{~g} \times 12 \mathrm{~m}^{2}=2040 \mathrm{~g} \approx 2 \mathrm{~kg}$. Deodoric ${ }^{\circledR}$ was applied to the litter at $170 \mathrm{~g}$ per $1 \mathrm{~m}^{2}$ once a week. 


\subsection{Measurements}

Birds were weighed individually once a week, beginning from the first day of the laying season (5 December 2016) $(n=8)$. Ammonia concentrations were measured twice a day (in the morning at 8 a.m. and afternoon at 3 p.m.) $(n=104)$ in both groups. The following performance parameters were determined: Body weight $(\mathrm{kg})$, average egg weight $(\mathrm{g})(n=83)$, egg production (eggs) $(n=83)$ and \% hen day egg production $(\%)\left(\frac{\text { daily number of eggs laid }}{\text { number of hens }} \times 100 \%\right)(n=83)$. Selected microclimate parameters $(n=52)$ were monitored in both poultry houses: Air humidity and temperature were measured with the ST-8820 Multi-Function Environment Meter (CEM, Shenzhen, China), air flow and cooling with Hill's dry kata-thermometer (Technical and Laboratory Glass Manufacturing Plant GOMAR, Warsaw, Poland), $\mathrm{NH}_{3}$ concentration with the Dräger $\mathrm{X}$-am ${ }^{\circledR} 5000$ gas detector (Drägerwerk AG \& Co. KGaA, Lübeck, Germany). The devices were validated before the experiment by producent. Ammonia and microclimate parameters were monitored from 25 October 2016 until the end of the experiment.

\subsection{Bacteriological Identification Methods}

One swab from each bird's air sacks, trachea, beak, sternum, and feet were collected for microbiological examinations upon slaughter. The samples were transported to the bacteriological laboratory at the Department of Microbiology and Clinical Immunology, Faculty of Veterinary Medicine. The swabs were placed in tryptone soya broth (TSB) liquid medium (Oxoid, Basingstoke, UK) and incubated at $40.5 \pm 2{ }^{\circ} \mathrm{C}$ for $24 \mathrm{~h}$ to detect aerobic bacteria. The following selective-differentiating media were used: MacConkey agar (Oxoid, Basingstoke, UK) for Enterobacteriaceae, Brilliance ${ }^{\mathrm{TM}}$ Salmonella Agar (Oxoid, Basingstoke, UK) for Salmonella spp., Edwards medium with the addition of 5\% sheep blood (Oxoid, Basingstoke, UK) for Enterococcus spp. and Streptococcus spp., Chapman medium (Oxoid, Basingstoke, UK) for Staphylococcus spp., and Columbia agar with the addition of $5 \%$ sheep blood (Oxoid, Basingstoke, UK) for bacteria with higher nutritional requirements. The swabs were incubated in Schaedler liquid medium (Oxoid, Basingstoke, UK) at $40.5 \pm 2{ }^{\circ} \mathrm{C}$ for $24 \mathrm{~h}$ under anaerobic conditions in GAS-Pack-Kit (Oxoid, Basingstoke, UK) to determine the presence of anaerobic bacteria. Germinated bacterial colonies were identified on the basis of morphological characteristics (color, colony shape, Gram stain, catalase test, cytochrome oxidase test, hemolysis type, coagulase test) and, subsequently, with the use of API ${ }^{\circledR}$ biochemistry tests (BioMerieux Vitek, France), Staphytec Plus latex tests, a Streptococcal grouping kit and the Salmonella Rapid Kit (Oxoid, Basingstoke, UK).

\subsection{Quantitative Microbiological Analyses}

Collective samples consisting of $10 \mathrm{~g}$ of chicken manure, collected once every two weeks, were transferred to an Erlenmeyer flask containing $90 \mathrm{~cm}^{3}$ of $0.85 \% \mathrm{NaCl}$ and were shaken on a shaker for $15 \mathrm{~min}$. The shaken sample was left for around $5 \mathrm{~min}$ to settle. The resulting solution was a $10^{-1}$ dilution, and a further decimal dilution was prepared. The counts of mesophilic bacteria and Campylobacter spp. were determined by culturing casting plates, where $1 \mathrm{~mL}$ of the suspension was collected from the prepared dilutions in triplicate. The number of colonies was counted after $24 \mathrm{~h}$, taking into account the dilution, and the result was expressed per $1 \mathrm{~g}$ of poultry manure.

\subsection{Statistical Analysis}

The influence of the deodorizing preparation on $\mathrm{NH}_{3}$ concentration in groups and significant differences in the body weight of hens, average egg weight, number of eggs laid, and \% hen day egg production between groups were determined in t-student test for independent samples. A multiple regression model was developed to determine the influence of $\mathrm{NH}_{3}$ on the body weight of hens, the number of eggs laid, and \% hen day egg production in group $\mathrm{C}$ and group $\mathrm{E}$. The influence of the applied dose of the deodorizing preparation (2 $\mathrm{kg}$ once a week) on $\mathrm{NH}_{3}$ concentration was determined with the use of t-student's test for dependent samples. Differences in environmental standards (temperature, humidity, air flow, cooling) between groups $C$ and $E$ were determined with 
the use of t-student's test for independent samples. A linear correlation model was built to illustrate the correlations between environmental conditions, age of birds, and $\mathrm{NH}_{3}$ concentration. The influence of hygiene conditions on $\mathrm{NH}_{3}$ concentration in both groups was evaluated with the use of a multiple regression model. Before performing multiple regression, the assumption of linearity and normality was checked. In order to demonstrate linearity, the data was analyzed for two-dimensional scatterplots of the variables studied. To check the assumptions of normality, distributions of variables were checked by histograms and normality charts for residues. A t-student's test for independent samples was applied to demonstrate the significant influence of the deodorizing preparation on $\mathrm{NH}_{3}$ concentration in groups and on differences in the body weight $(\mathrm{kg})$ of hens between groups. The influence of $\mathrm{NH}_{3}$ concentration on the body weight of hens, a lower number of eggs laid, and lower \% hen day egg production in groups $C$ and $E$ was evaluated with the use of a multiple regression model. Differences in days and for entire model in the counts of mesophilic microorganisms and Campylobacter spp. isolated from litter were analysed using ANOVA for repeated measurements. The k-nearest neighbors algorithm was performed to exclude statistical anomalies in microbiological tests. Standard deviation (SD), median (ME), mode (MO) and variances (V) were also calculated. Differences where the $p$-value was less than 0.05 were considered significant. Data were processed statistically in the Statistica 13.1 program with a medical application (Dell Computer Corporation, Round Rock, USA).

\section{Results}

Before applying Deodoric ${ }^{\circledR}$ to the litter there were no statistically significant differences in the measured environmental parameters: Temperature ( $p$-value $=0.8)$, humidity $(p$-value $=0.69)$, air flow $(p$-value $=0.74)$, cooling $(p$-value $=0.63)$ between group $\mathrm{C}$ and $\mathrm{E}$.

During the experiment, average hens' weight in group $\mathrm{E}$ increased by $51.22 \%$, in group $\mathrm{C}$ by $44.31 \%$. Hens from group $\mathrm{C}$ laid 2599 eggs with an average weight of 66.44g (SD, 3.47; ME, 66.35; MO, $66.4 ; \mathrm{V}, 11.44)$, hens from group and $\mathrm{E}$ laid 2755 eggs with an average weight of $66.81 \mathrm{~g}$ (SD, 3.16; ME, $66.95 ; \mathrm{MO}, 66.9 ; \mathrm{V}, 9.89)$. The results of the measurements of $\mathrm{NH}_{3}$ levels and selected microclimate parameters from the start of the experiment to the end of the experiment were placed in Table 1.

Table 1. Measurements of ammonia concentration and zoohygienic parameters from the start of administration of the preparation until the end of the experiment in control group (group C) and experimental group (group E).

\begin{tabular}{ccccccccccccc}
\hline \multirow{2}{*}{ Measured Parameters } & \multicolumn{4}{c}{ Control Group } & \multicolumn{4}{c}{ Experimental Group } & \multicolumn{1}{c}{ E Group vs. C Group } \\
\cline { 2 - 12 } & $\overline{\mathbf{x}}$ & SD & ME & MO & V & $\overline{\mathbf{x}}$ & SD & ME & MO & V & $p$-Value \\
\hline $\mathrm{NH}_{3}$ concentration $(\mathrm{ppm})$ & 12.44 & 4.79 & 12 & 10 & 22.92 & 6.70 & 7.25 & 5.00 & 0.00 & 31.12 & 0.001 \\
Temperature $\left({ }^{\circ} \mathrm{C}\right)$ & 20.34 & 1.11 & 20.40 & 20.30 & 1.22 & 20.46 & 0.71 & 20.40 & 20.50 & 0.51 & 0.68 \\
Humidity $(\%)$ & 56.785 & 3.80 & 56.85 & $\mathrm{~m}$ & 7.45 & 50.78 & 3.34 & 49.52 & $\mathrm{~m}$ & 11.14 & 0.006 \\
Air flow $(\mathrm{m} / \mathrm{s})$ & 0.078 & 0.056 & 0.65 & $\mathrm{~m}$ & 0.003 & 0.073 & 0.040 & 0.051 & 0.05 & 0.001 & 0.71 & 0.74 \\
Cooling $\left(\mathrm{W} / \mathrm{m}^{2}\right)$ & 2.07 & 0.22 & 1.98 & 2.04 & 0.046 & 2.05 & 0.13 & 1.95 & 2.03 & 0.018 & \\
\hline
\end{tabular}

Note: Legend: $\bar{x}$, mean; $\mathrm{SD}$, standard deviation; ME, median; MO, mode; $\mathrm{V}$, variance; $\mathrm{m}$, multiple; $\mathrm{C}$, control; E, experimental.

Significant differences in $\mathrm{NH}_{3}$ concentration $(p$-value $=0.001)$, body weight of hens $(p$-value $=0.025)$, and humidity $(p$-value $=0.006$ ) were observed between group $\mathrm{C}$ and group $\mathrm{E}$. The differences in mean egg weight $(p$-value $=0.75)$, number of eggs laid $(p$-value $=0.58), \%$ hen day egg production $(p$-value $=0.22)$, temperature $(p$-value $=0.68)$, air flow $(p$-value $=0.71)$, and cooling $(p$-value $=0.74)$ between group $\mathrm{C}$ and group $\mathrm{E}$ were not significant. In group $\mathrm{C}$, an increase in $\mathrm{NH}_{3}$ concentration contributed to lower body weight of hens, a lower number of eggs laid, and lower \% hen day egg production (for body weight: $\beta=-0.21, p$-value $=0.017$; for number of eggs: $\beta=-0.13 ., p$-value $=0.037$; for $\%$ hen day egg production: $\beta=-0.11, p$-value $=0.042$ ). No significant correlations were observed in group E. The comparison of multiple linear regression models showed statistically significant differences $(p$-value $=0.0035)$.

A moderate linear correlation between $\mathrm{NH}_{3}$ concentration vs. temperature, humidity, air flow, and weak linear correlation between $\mathrm{NH}_{3}$ concentration and age of hens in group $\mathrm{C}$ were noted. In group 
E, $\mathrm{NH}_{3}$ concentration vs. temperature and humidity were weakly correlated. Detailed correlation results are in Table 2.

Table 2. The correlations between environmental parameters in hen houses (Pearson's correlation coefficient $r$ ).

\begin{tabular}{ccccc}
\hline Correlations between & \multicolumn{2}{c}{ Control Group } & \multicolumn{2}{c}{ Experimental Group } \\
\cline { 2 - 5 } Environmental Parameters & $\boldsymbol{p}$-Value & $\boldsymbol{r}$ Coefficient & $\boldsymbol{p}$-Value & $\boldsymbol{r}$ Coefficient \\
\hline $\mathrm{NH}_{3}$ /temperature & 0.09 & 0.64 & 0.03 & 0.27 \\
$\mathrm{NH}_{3}$ /humidity & 0.03 & 0.68 & 0.027 & 0.14 \\
$\mathrm{NH}_{3}$ /air flow & 0.02 & 0.48 & 0.32 & 0.22 \\
$\mathrm{NH}_{3}$ /cooling & 0.23 & 0.26 & 0.33 & 0.22 \\
$\mathrm{NH}_{3}$ /age & 0.007 & 0.27 & 0.51 & 0.065 \\
\hline
\end{tabular}

$r$-Pearson's correlation coefficient, $p<0.05$.

The multiple regression model for group $\mathrm{C}$ indicates that $\mathrm{NH}_{3}$ concentration was influenced mostly by temperature which was most highly correlated with other variables in the model $(F=12.11$, $p$-value $=0.012)$. In group $\mathrm{E}$, the multiple regression model was not statistically significant $(p$-value $=0.09)$.

Statistical analysis of changes in the counts of mesophilic microorganisms isolated from manure revealed a significant decrease on day 28 in group E. Differences were not found between groups on the remaining days of the experiment (Figure 1). An analysis of changes in the counts of Campylobacter spp. isolated from manure demonstrated that their proliferation was inhibited on days 14 and 84 in group E (Figure 2). However, for the entire experimental model no statistically significant changes in the number of Campylobacter spp. (for entire model, $\mathrm{df}$ (degrees of freedom) $=1, F=46.14, p$-value $=0.093$; for $C$ vs. $E, d f=9, F=3.29, p$-value $=0.045$ ) and in the number of mesophilic bacteria (for entire model, $\mathrm{df}=1, F=3.29, p$-value $=0.32$; for $\mathrm{C}$ vs. $\mathrm{E}, \mathrm{df}=7, F=0.98, p$-value $=0.51$ ) were found. Results of k-nearest neighbors algorithm for microbiological tests indicate that the deviation of mesophilic bacteria in the 28th day and Campylobacter spp. in the 14th and 84th days should be considered as statistical anomaly.

A qualitative analysis of microbiological swabs collected from various areas of the body in both groups did not reveal differences in the microbiome.

Mesophilic bacteria

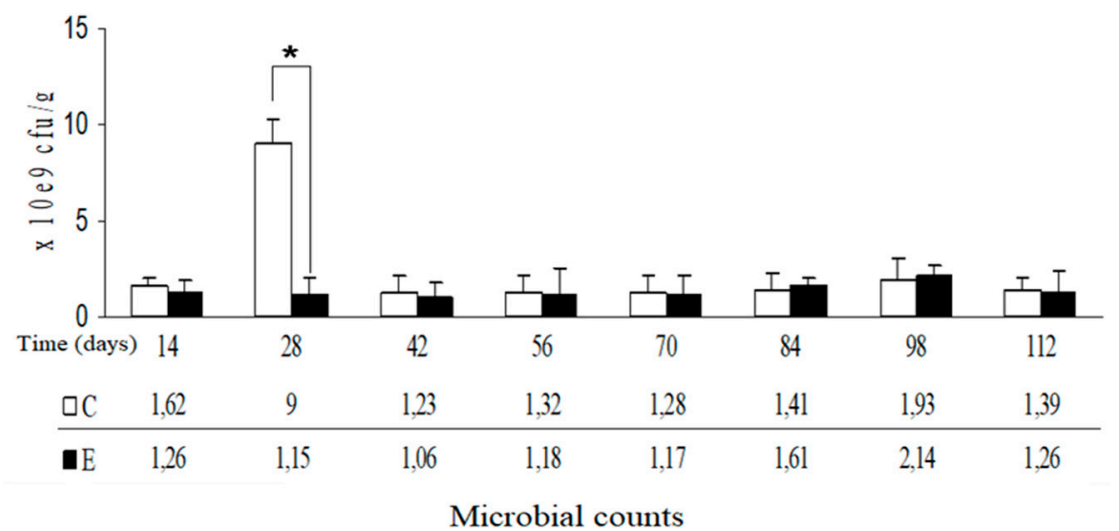

Figure 1. Changes in mesophilic microbial counts during the experiment. ${ }^{*} p$-value $\leq 0.05$. 


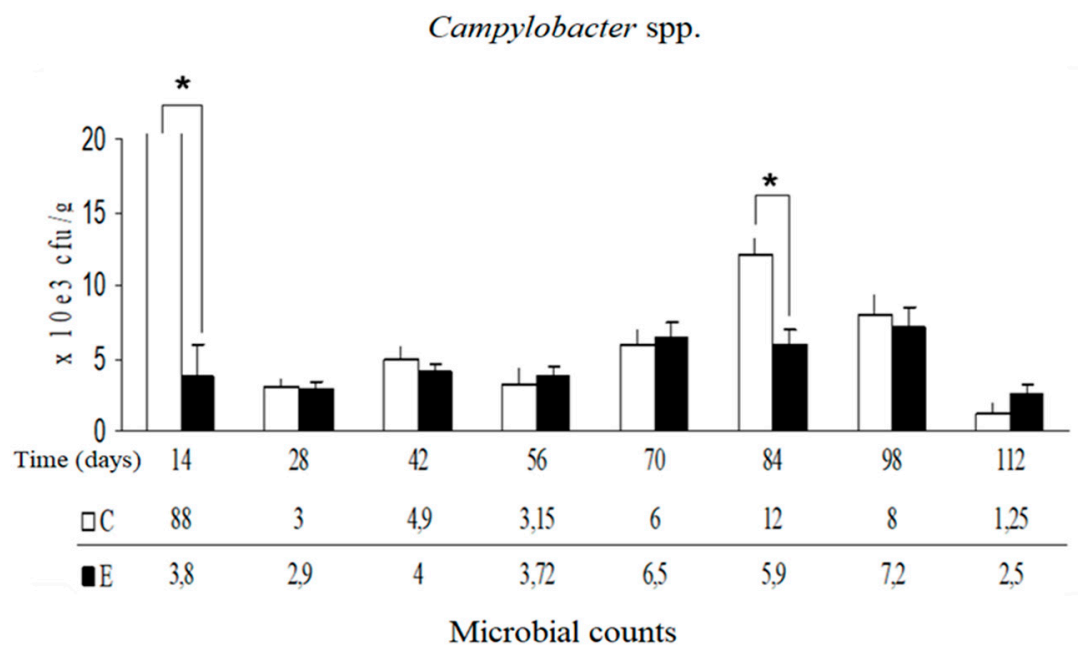

Figure 2. The results of student's t-test for body weight of laying hens in the control group (group C, without Deodoric ${ }^{\circledR}$ ) and the experimental group (group E, with Deodoric ${ }^{\circledR}$ ). ${ }^{*} p$-value $\leq 0.05$.

\section{Discussion}

Numerous studies have demonstrated the adverse effects of $\mathrm{NH}_{3}$ on poultry performance $[11,13]$. According to other authors, high $\mathrm{NH}_{3}$ concentrations have a negative influence on performance indicators in poultry. Ammonia considerably affects the body weight of hens, increases the feed conversion ratio, prolongs the rearing period, and contributes to secondary infections [30,31]. Ammonia contamination can cause financial losses in poultry production [32]. The Deodoric ${ }^{\circledR}$ preparation minimized the adverse effects of $\mathrm{NH}_{3}$ on the body weight of hens. A significant increase in $\mathrm{NH}_{3}$ levels (200 ppm over 17 days) significantly decreased \% hen day egg production, egg weight, and feed intake [33]. These adverse effects were not noted in the present study because $\mathrm{NH}_{3}$ concentration was much lower.

Other deodorizing preparations including substances like alum and sulfate heptahydrate can be toxic at high concentrations, and they can lead to the excessive accumulation of harmful compounds in the environment. Tested preparation retained nitrogen in chicken manure and may constitute as excellent fertilizer without any harmful effects on the environment. Microbiological gases have also been used to control $\mathrm{NH}_{3}$ emissions, but their effectiveness was ambiguous. Based on studies performed by Matusiak et al. [24], we believe that combining Deodoric ${ }^{\circledR}$ with other preparations like Yucca schidigera extract can bring even more positive results and reduce the dosage of tested preparation.

A qualitative analysis of swabs collected from the respiratory tract and selected areas on the surface of the body did not reveal differences in their microbial composition. These results could indicate that Deodoric ${ }^{\circledR}$ did not modify the microflora inhabiting the examined areas. The absence of differences in the examined groups may suggest that the preparation did not interfere with microbiological homeostasis and may not affect the activity of local immunological structures (mucosa-associated lymphatic tissue (MALT) and skin-associated lymphoid tissues (SALT)). However, we believe that the impact of the preparation in particular on the immune system requires further research.

Significant differences in $\mathrm{NH}_{3}$ concentration and humidity were observed between group $\mathrm{C}$ and group E. Differences in humidity between studied groups may be caused by a bentonite carrier which has a drying effect of manure. Due to the fact that, according to earlier studies, a dose of $0.4-0.8 \mathrm{~kg} / \mathrm{m}^{2}$ of manure did not significantly affect the concentration of ammonia [34], we believe that the microbiological part influenced the ammonia concentration significantly. Similar results were obtained by Majewski et al. [35] with bentonite dosage of $1.5 \mathrm{~kg} / \mathrm{m}^{2}$ litter in decreasing ammonia concentration. This observation proves the mechanism of action of Deodoric ${ }^{\circledR}$ preparation in reducing $\mathrm{NH}_{3}$ concentration in poultry houses. 
Due to the economic aspect, we believe that the best period to use this preparation is $15-16$ weeks of a hen's life. During this period, the hens are moved from the rearing house to the production hall. To speed up the laying process, the length of the light day regiment increases and the feed becomes more concentrated in nutrients. These factors and stress caused by breeding procedures increase nitrogen compounds in the litter, which can lead to an increase in ammonia concentration in the poultry house. We believe that this is the optimal time to start using the product. The presented experiment indicates that the biopreparation can be used especially in barn-reared and free-range farming. In the case of cage farming, its application may be difficult and, due to inadequate distribution of the preparation, ineffective. According to our observations, the preparation can be used in the production of eggs in the intensive, semi-intensive, or extensive systems. If the ammonia concentration exceeds the permissible standards in the house, Deodoric ${ }^{\circledR}$ should be used regularly at the dose recommended by us. In our opinion, if $\mathrm{NH}_{3}$ stabilizes at an optimal level, the dose can be reduced by half as a maintenance dose. However, any reduction in Deodoric ${ }^{\circledR}$ dose should be documented in further field studies. The tested preparation may have a positive effect especially from the beginning to the peak of laying.

Previous studies demonstrated that ammonia levels in poultry houses are closely linked with selected microclimate parameters [36-40]. According to Elliott and Collins [36], $\mathrm{NH}_{3}$ volatilization is influenced mainly by litter $\mathrm{pH}$, temperature, and relative humidity. $\mathrm{Ni}$ [37] reported that $\mathrm{NH}_{3}$ concentration is very closely related to air velocity on manure surface and the temperature of air or manure. Nimmermark and Gustafsson [38] suggested that temperature and relative humidity control may decrease ammonia concentrations and emissions. Other authors also observed correlations between $\mathrm{NH}_{3}$ volatilization vs. temperature, relative humidity, ventilation rate, and the $\mathrm{pH}$ level of manure [39,40]. In the present study, similar relationships were observed in group C. The results of our study point to a linear relationship between $\mathrm{NH}_{3}$ concentration vs. temperature, relative humidity, and air flow in group $\mathrm{C}$. In group $\mathrm{E}$, the correlations between $\mathrm{NH}_{3}$ concentration and the studied parameters were not statistically significant. These findings suggest that the tested biopreparation minimized the correlations between microclimate parameters and ammonia concentration in air. In addition, the absence of a linear correlation between ammonia concentration and air flow/cooling in group $\mathrm{E}$ indicates that room ventilation did not distort the obtained results. Statistically significant correlations between ammonia concentration and air flow/cooling in group $\mathrm{C}$ could be caused by periodically increased ventilation. This factor could have influenced the results in group $\mathrm{C}$, but turkey premises had to be ventilated because very high ammonia concentrations (up to $46 \mathrm{ppm}$ ) in group C posed a threat to the experimental animals. The absence of linear relationships in group E could be attributed to the properties of the tested preparation, including manure drying, decrease in $\mathrm{pH}$, and microbial competition for biological compounds present in litter [27,28].

\section{Conclusions}

Deodoric ${ }^{\circledR}$ contributed to animal welfare by reducing the concentrations of ammonia in poultry houses. The tested biopreparation can be used to improve the productive performance of poultry farms (it is the first preparation that can be applied directly to litter during animal rearing) and minimized noxious odors in the vicinity of poultry farms. The tested product also increased the safety of farm personnel by alleviating the adverse health consequences of $\mathrm{NH}_{3}$ emissions. It exerts a stabilizing effect on the microbiological environment of farm animals without affecting the body's biofilm, and it can minimize losses associated with unnecessary immune responses. The tested deodorizing preparation is recommended for use in poultry farms to improve animal health and performance and to generate benefits for producers.

Author Contributions: R.G. and T.B., conceived, designed, performed the experiments; analyzed the data; wrote the paper; and corrected the manuscript. M.D. and K.O. conceived, designed, and performed the experiments; and analyzed the data. A.N. analyzed the data. T.B. and B.G. developed the research concept. 
Funding: The study was funded by the Polish National Centre for Research and Development as part of the project entitled "Innovative deodorizing biopreparation for poultry farmhouses", grant No. PBS2/B8/14/2014. Project financially co-supported by minister of Science and Higher Education in the range of the program entitled "Regional lnitiative of Excellence" for the years 2019-2022, Project No. 010/RID/2018/19, amount of funding 12.000.000 PLN.

Conflicts of Interest: The authors declare no conflict of interest.

\section{References}

1. Koziel, J.A.; Aneja, V.P.; Baek, B.H. Gas-to-particle conversion process between ammonia, acid gases, and fine particles in the atmosphere. ASABE 2006, 201-224. [CrossRef]

2. Maurer, D.L.; Koziel, J.A.; Harmon, J.D.; Hoff, S.J.; Hinz, A.M.; Andersen, D.S. Summary of performance data for technologies to control gaseous, odor, and particulate emissions from livestock operations: Air management practices assessment tool (AMPAT). Data Brief. 2016, 7, 1413-1429. [CrossRef] [PubMed]

3. Bouwman, A.F.; Lee, D.S.; Asman, W.A.H.; Dentener, F.J.; Van Der Hoek, K.W.; Olivier, J.G.J. A global high-resolution emission inventory for ammonia. Glob. Biogeochem. Cycles 1997, 11, 561-587. [CrossRef]

4. Xu, R.; Tian, H.; Pan, S.; Prior, S.A.; Feng, Y.; Batchelor, W.D.; Chen, J.; Yang, J. Global ammonia emissions from synthetic nitrogen fertilizer applications in agricultural systems: Empirical and process-based estimates and uncertainty. Glob. Chang. Biol. 2019, 25, 314-326. [CrossRef] [PubMed]

5. Webb, J.; Menzi, H.; Pain, B.F.; Misselbrook, T.H.; Dämmgen, U.; Hendriks, H.; Döhler, H. Managing ammonia emissions from livestock production in Europe. Environ. Pollut. 2005, 135, 399-406. [CrossRef] [PubMed]

6. Groenestein, C.M.; Hutchings, N.J.; Haenel, H.D.; Amon, B.; Menzi, H.; Mikkelsen, M.H.; Misselbrook, T.H.; van Bruggen, C.; Kupper, T.; Webb, J. Comparison of ammonia emissions related to nitrogen use efficiency of livestock production in Europe. J. Clean. Prod. 2019, 211, 1162-1170. [CrossRef]

7. Van der Hoek, K.W. Estimating ammonia emission factors in Europe: Summary of the work of the UNECE ammonia expert panel. Atmos. Environ. 1998, 32, 315-316. [CrossRef]

8. Eurich-Menden, B.; Döhler, H.; Dämmgen, U. Ammoniak-Emissionen der deutschen Landwirtschaft-technische minderungspotenziale. Landtech. Agric. Eng. 2004, 59, 162-163. (In German)

9. Regulation of the minister of Agriculture and Rural Development of February 15, 2010 on the requirements and conduct of behavior in keeping species of farm animals for which protection standards have been defined in the European Union legislation. J. Laws 2010, 56, 344.

10. American Conference of Governmental Industrial Hygienists. Threshold Limit Values (TLVs) and Biological and Exposure Indices (BEIs); ACGIH: Cincinnati, OH, USA, 2001; pp. 72-75.

11. Ritz, C.W.; Fairchild, B.D.; Lacy, M.P. Implications of ammonia production and emissions from commercial poultry facilities: A review. J. Appl. Poult. Res. 2004, 13, 684-692. [CrossRef]

12. Miles, D.M.; Branton, S.L.; Lott, B.D.; Simmons, J.D. Quantified detriment of ammonia to broilers. Poult. Sci. 2002, 81, 54-55.

13. Beker, A.; Vanhooser, S.L.; Swartzlander, J.H.; Teeter, R.G. Atmospheric ammonia concentration effects on broiler growth and performance. J. Appl. Poult. Res. 2004, 13, 5-9. [CrossRef]

14. Donham, K.J.; Cumro, D.; Reynolds, S.J.; Merchant, J.A. Dose-Response Relationships Between Occupational Aerosol Exposures and Cross-Shift Declines of Lung Function in Poultry Workers: Recommendations for Exposure Limits. J. Occup. Environ. Med. 2000, 42, 260-269. [CrossRef] [PubMed]

15. Viegas, S.; Faísca, V.M.; Dias, H.; Clérigo, A.; Carolino, E.; Viegas, C. Occupational exposure to poultry dust and effects on the respiratory system in workers. J. Toxicol. Environ. Health Part A 2013, 76, 230-239. [CrossRef] [PubMed]

16. Nowak, A.; Matusiak, K.; Borowski, S.; Bakuła, T.; Opaliński, S.; Kołacz, R.; Gutarowska, B. Cytotoxicity of odorous compounds from poultry manure. Int. J. Environ. Res. Public Health 2016, 13, 1046. [CrossRef]

17. Nowak, A.; Bakuła, T.; Matusiak, K.; Gałęcki, R.; Borowski, S.; Gutarowska, B. Odorous Compounds from Poultry Manure Induce DNA Damage, Nuclear Changes, and Decrease Cell Membrane Integrity in Chicken Liver Hepatocellular Carcinoma Cells. Int. J. Environ. Res. Public Health 2017, 14, 933. [CrossRef]

18. Dawkins, M.S.; Donnelly, C.A.; Jones, T.A. Chicken welfare is influenced more by housing conditions than by stocking density. Nature 2004, 427, 342-344. [CrossRef]

19. Whyte, R.T. Aerial pollutants and the health of poultry farmers. Worlds Poult. Sci. J. 1993, 49, $139-156$. [CrossRef] 
20. Hartung, E.; Jungbluth, T.; Bascher, W. Reduction of ammonia and odor emissions from a piggery with biofilters. Trans. ASAE 2001, 44, 113. [CrossRef]

21. DeLaune, P.B.; Moore, P.A.; Daniel, T.C.; Lemunyon, J.L. Effect of chemical and microbial amendments on ammonia volatilization from composting poultry litter. J. Environ. Qual. 2004, 33, 728-734. [CrossRef]

22. Li, H.; Xin, H.; Liang, Y.; Burns, R.T. Reduction of ammonia emissions from stored laying hen manure through topical application of zeolite, Al+ Clear, Ferix-3, or poultry litter treatment. J. Appl. Poult. Res. 2008, 17, 421-431. [CrossRef]

23. Santoso, U.; Ohtani, S.; Tanaka, K.; Sakaida, M. Dried Bacillus subtilis culture reduced ammonia gas release in poultry house. Asian-Australas. J. Anim. Sci. 1999, 12, 806-809. [CrossRef]

24. Matusiak, K.; Oleksy, M.; Borowski, S.; Nowak, A.; Korczyński, M.; Dobrzański, Z.; Gutarowska, B. The use of Yucca schidigera and microbial preparation for poultry manure deodorization and hygienization. J. Environ. Manag. 2016, 170, 50-59. [CrossRef] [PubMed]

25. Borowski, S.; Gutarowska, B.; Brycki, B.; Kołacz, R. Method of preparation of biopreparation for deodorization of poultry manure. International Patent P-393863, 7 February 2011. (In Polish).

26. Matusiak, K.; Borowski, S.; Opaliński, S.; Bakuła, T.; Kołacz, R.; Gutarowska, B. Impact of a microbial-mineral biopreparation on microbial community and deodorization of manures. Acta Biochim. Pol. 2015, 62, 791-798. [CrossRef]

27. Borowski, S.; Matusiak, K.; Powałowski, S.; Pielech-Przybylska, K.; Makowski, K.; Nowak, A.; Rosowski, M.; Komorowski, P.; Gutarowska, B. A novel microbial-mineral preparation for the removal of offensive odors from poultry manure. Int. Biodeterior. Biodegrad. 2016, 119, 299-308. [CrossRef]

28. Gutarowska, B.; Matusiak, K.; Borowski, S.; Rajkowska, A.; Brycki, B. Removal of odorous compounds from poultry manure by microorganisms on perlite-bentonite carrier. J. Environ. Manag. 2014, 141, 70-76. [CrossRef]

29. National Research Council. Guide for the Care and Use of Laboratory Animals; National Academy Press: Washington, DC, USA, 2010; pp. 1-246.

30. Miles, D.M.; Branton, S.L.; Lott, B.D. Atmospheric ammonia is detrimental to the performance of modern commercial broilers. Poult. Sci. 2004, 83, 1650-1654. [CrossRef]

31. Vučemilo, M.; Matković, K.; Vinković, B.; Jakšić, S.; Granić, K.; Mas, N. The effect of animal age on air pollutant concentration in a broiler house. Czech J. Anim. Sci. 2007, 52, 170-174. [CrossRef]

32. Carlile, F.S. Ammonia in poultry houses: A literature review. Worlds Poult. Sci. J. 1984, 40, 99-113. [CrossRef]

33. Deaton, J.W.; Reece, F.N.; Lott, B.D. Effect of atmospheric ammonia on laying hen performance. Poult. Sci. 1982, 61, 1815-1817. [CrossRef]

34. Sevi, A.; Muscio, A.; Campanaro, G.; Dantone, D. Environmental control in animal houses. Effect of litter treatments with bentonite on air quality and broilers performance. Arch. Vet. Ital. 1995, 46, 113-121.

35. Majewski, T.; Podgorski, W.; Polonis, A.; Tymczyna, L. Effect of adding natural aluminosilicate (bentonite) on the sanitary conditions and growth of broiler chickens. Rocz. Nauk. Zootech. 1995, 22, 371-381.

36. Elliott, H.A.; Collins, N.E. Factors affecting ammonia release in broiler houses. Trans. ASAE 1982, 25, 413-418. [CrossRef]

37. Ni, J. Mechanistic models of ammonia release from liquid manure: A review. J. Agric. Eng. Res. 1999, 72, 1-17. [CrossRef]

38. Nimmermark, S.; Gustafsson, G. Influence of temperature, humidity and ventilation rate on the release of odour and ammonia in a floor housing system for laying hens. Agric. Eng. Int. CIGR E-J. 2005, 7, 1-4.

39. Pagans, E.; Barrena, R.; Font, X.; Sánchez, A. Ammonia emissions from the composting of different organic wastes. Dependency on process temperature. Chemosphere 2006, 62, 1534-1542. [CrossRef]

40. Sommer, S.G.; Zhang, G.Q.; Bannink, A.; Chadwick, D.; Misselbrook, T.; Hutchings, N.J.; Menzi, H.; Monteny, G.J.; Ni, J.Q.; Oenema, O.; et al. Algorithms determining ammonia emission from buildings housing cattle and pigs and from manure stores. Adv. Agron. 2006, 89, 261-335.

(C) 2019 by the authors. Licensee MDPI, Basel, Switzerland. This article is an open access article distributed under the terms and conditions of the Creative Commons Attribution (CC BY) license (http://creativecommons.org/licenses/by/4.0/). 